Sesję tą zakończyła krótka dyskusja.

Druga sesja tego dnia poświęcona była historii prawa rzymskiego, a przewodniczył jej prof. Tomasz Giaro z Uniwersytetu Warszawskiego. Pierwsze referaty wygłosili prof. Bronisław Sitek (UW-M): Stosowanie prawa rzymskiego w ustawach municypalnych. Studium prawno-historyczne na tle 'Tabula Heracleensis' $i$ 'lex Irnitana', dr Marek Sobczyk (UMK): Prawo rzymskie przed Europejskim Trybunałem Sprawiedliwości i dr Lukasz Marzec (UJ): Wizja prawa rzymskiego w Europie w świetle poglądów Artura Ducka. Kolejnymi referentami byli ks. dr Stanisław Jóźwiak (KUL): Rola biskupa w państwie rzymskim w świetle korespondencji św. Augustyna oraz dr Miron Wolny (UW-M): Lex Claudia a rozwój kariery politycznej Gajusza Flaminiusza. Sesję zakończyły wystąpienia mgr Renaty Wiadernej-Kuśnierz (UMCS): Prawo rzymskie na Uniwersytecie Jana Kazimierza we Lwowie w okresie międzywojennym i mgr Karoliny Chytły (UJ): Prawo rzymskie kluczem do zrozumienia dziedzictwa prawa prywatnego Europy.

Spotkanie zamknęła dyskusja nad przyszłością polskiej romanistyki.

Agnieszka Stępkowska*

\title{
'CUIUS REGIO EIUS RELIGIO?' - ZJAZD HISTORYKÓW PAŃSTWA I PRAWA, LUBLIN 22-24 WRZEŚNIA 2006 ROKU
}

W dniach 22-24 września 2006 r. odbył się zorganizowany przez Katedrę Historii Państwa i Prawa Katolickiego Uniwersytetu Lubelskiego Zjazd Historyków Państwa i Prawa. Wzięli w nim udział przedstawiciele ośrodków uniwersyteckich w Polsce. Łącznie referaty wygłosiło 60 osób.

Zjazd otworzył - rano w piątek 22 września w Collegium Jana Pawła II - prof. Grzegorz Górski, Kierownik Katedry Państwa i Prawa KUL. Powitał on przybyłych, a następnie uczynił to ks.

\footnotetext{
* Uniwersytet Warszawski.
} 
prof. Antoni Dębiński, Dziekan WPPKiA KUL oraz prof. Józef Franciszek Fert, Prorektor KUL. Po powitaniach minutą ciszy uczczono niedawno zmarłych dwóch wybitnych przedstawicieli nauk historyczno-prawnych, prof. Stanisława Płazę z Katedry Historii Prawa Polskiego UJ i prof. Edwarda Szymoszka, Kierownika Katedry Prawa Rzymskiego UŚ i UWr.

Po uroczystym otwarciu Zjazdu rozpoczęła się Sesja plenarna. Przewodniczył jej prof. Adam Lityński z UŚ. Jako pierwszy wystąpił prof. Wacław Uruszczak z UJ, który mówił na temat: Rola Kościoła w rozwoju parlamentaryzmu w średniowiecznej Polsce, a następnie: prof. Tadeusz Maciejewski z UG - Wplyw Reformacji na przemiany ustroju miast pruskich w I potowie XVI wieku, prof. Andrzej Zakrzewski z UW - Wielkie Księstwo Litewskie wobec problemów wyznaniowych w XIV-XVIII w., prof. Marian Kallas z UKSW - Miejsce religii $i$ Kościoła rzymskokatolickiego w polskich aktach, prof. Micha1 Pietrzak z UW - Francuska ustawa o rozdziale Kosciola i państwa z $1905 r$ oraz prof. Adam Lityński z UŚ - O pojęciu praworzadności socjalistycznej w Polsce Ludowej.

Nad przedstawionymi referatami odbyła się dyskusja.

Obrady w sesji popołudniowej odbywały się w trzech sekcjach.

Sekcji I, romanistycznej, przewodniczył prof. Andrzej Sokala z UMK, a referaty wygłosili prof. Bronisław Sitek z UM-W zatytulowany $O$ Edykcie Teodozjusza 'de fide catholica'. Krótkie uwagi o tolerancji, mgr Paulina Święcicka z UJ - Wybrane zmiany fragmentów dotyczacych odpowiedzialnosici akwiliańskiej dokonane w okresie poklasycznym i justyniańskim, których przyczyna mogta być doktryna chrześcijańska - czy rzeczywiście byta?, dr Aldona Jurewicz z UW-M - Swoboda religijna niewolników w Rzymie, dr Rafal Wojciechowski z UWr - 'Ne Christianum mancipium Iudaeus habeat', dr Marzena Dyjakowska z KUL - Procesy chrzescijan $w$ swietle korespondencji Pliniusza Mtodszego, dr Jacek Wiewiorowski z UAM - Uprawnienia gubernatora późnorzymskiego $w$ sprawach religijnych oraz dr Jakub Urbanik z UW - Papinian czy Paweł - spór wokót rozwodów późnej starożytności. Sesja romanistyczna zakończyła się żywą dyskusją.

W ramach Sekcji II wygłoszono następujące referaty: mgr Anna 
Karabowicz z UJ - Stosunki wyznaniowe w Rzeczypospolitej za czasów Stefana Batorego w świetle ustawodawstwa sejmowego, dr Jerzy Kolarzowski z UW - Bracia polscy zwani arianami wobec konfliktów politycznych $w$ Rzeczypospolitej $w$ latach 1573-1638, dr Izabela Lewandowska-Malec z UJ - Spór Akademii Krakowskiej za panowania Zygmunta II $i$ Wtadystawa IV Wazów, prof. Marian Ptak z UWr Pokój Augsburski na Ślasku, mgr Maurycy Zajęcki z UAM - Przedmiot badan nauk historycznoprawnych z punktu widzenia ogólnej metodologii nauk, metodologii historii i teorii prawa (na przyktadzie pokoju augsburskiego jako fenomenu historycznego i prawnego), prof. dr hab. Marian Mikołajczyk z UŚ - Żydzi jako oskarżeni przed sq̨dami miejskimi w przedrozbiorowej Polsce, mgr Małgorzata Janiszewska z UAM - Próby upaństwowienia sadownictwa kościelnego w Polsce w XVIII wieku oraz dr Wojciech Organiściak z UŚ - Kościót w pogladach Wincentego Skrzetuskiego.

W ramach Sekcji III dr Mariusz Mohyluk z UwB wygłosił referat zatytułowany Poglady Kościoła katolickiego w II RP na temat prawa radzieckiego, a następnie dr Józef Koredczuk z UWr - Przysięga wyznaniowa $w$ polskim procesie karnym okresu międzywojennego, $\mathrm{dr}$ Maciej Marszał z UWr - Pakty laterańskie w polskiej myśli politycznej i prawnej okresu międzywojennego, dr Ewa Kozerska z UO - Sytuacja Koscioła katolickiego $w$ faszystowskich Wtoszech $w$ latach 1922-1939, dr Tomasz Scheffler z UWr - Kościoly w Trzeciej Rzeszy wobec reżimu hitlerowskiego, dr Tomasz Kotliński z Wyższej Szkoły Zawodowej w Jarosławiu - Sprawy wyznaniowe i narodowościowe $w$ adwokaturze polskiej, mgr Michał Gałędek z UG - Kompetencje administracji rzadowej $w$ kwestiach zwiazków wyznaniowych $w$ województwach pólnocno - wschodnich i na Wolyniu w latach 1920-1939, dr Andrzej Drogon - Niektóre problemy polityki wyznaniowej Sejmu Ślaskiego (1922-1939), dr Andrzej Szymański z UO - Prawo kanoniczne w państwie autorytarnym. O. Adolf Ledwolorz, o. Andrzej Bolczyk, o. Dominik Kiesch - Slascy kanoniści franciszkańscy XX w.

Sobotnia sesja poranna podzielona została również na trzy Sekcje.

Moderatorem obrad w Sekcji I został prof. Tadeusz Maciejewski z UG. Jako pierwszy wystąpił mgr Piotr Michalik z UJ, który wygło- 
sił referat zatytułowany Kilka uwag na temat cezaropapizmu w Cesarstwie Wschodniorzymskim i Bizantyjskim, a następnie kolejno: dr Mirosław Sadowski z UWr - Wczesnoislamska koncepcja władzy państwowej, dr Andrzej Gaca z UMK - Prawo kanoniczne, Kościót i duchowieństwo w postanowieniach Prawa Jutlandzkiego Waldemara II z 1241 roku, dr Ewaryst Kowalczyk z UAM - Pojecie $i$ modele średniowiecznej i nowożytnej dobroczynności, mgr Marek Zurek z UJ Późnośredniowieczne ustawodawstwo synodów polskich w sprawach małzeńskich, dr Ireneusz S. Grat z UwB - prawo do wolności sumienia $w$ kontekście prawa natury. Po wysłuchaniu ostatniego referatu wygłoszonego przez mgr Karola Kuźmicza z UwB - Filozofia religii Immanuela kanta jako przyczyna jego sporu z władza, Przewodniczący otworzył dyskusję.

W ramach Sekcji II przedstawiono następujące referaty: dr Marian Małecki z UJ - Reformy terezjańsko-józefińskie w Galicji, dr Marcin Kwiecień z UJ - Reformy stosunków między Państwem a Kosciolem w Wielkim Ksiestwie Toskanii 1765-1790, dr Katarzyna Maćkowska z KUL - Amerykańskie stany założycielskie jako model wspólnot wyznaniowych, dr Wojciech Szafrański z UAM - Kościoty i duchowni w projekcie konkursowym Wojciecha Olszowskiego do Kodeksu Stanistawa Augusta, mgr Jarosław Dudziński z UŚ - Wtadze insurekcji 1794 r a Kosciót, dr Jacek Przygodzki z UWr - Pozycja prawna ludnosci żydowskiej pod rzadami Rady Najwyższej Tymczasowej Ksiestwa Warszawskiego (1813-1815), dr Andrzej Gulczyński z UAM - 'Sacrum i profanum'. Ideowe treści cesarskiej rezydencji w Poznaniu, mgr Przemysław Dąbrowski z UG - Polscy konserwatysci i narodowi - demokraci wobec kwestii jezykowych w liturgii Koscioła katolickiego na ziemiach litewsko-biatoruskich na przetomie $X I X$ i $X X$ w., prof. Andrzej Dziadzio z UJ - Antysemityzm jako powód konfiskat prasowych. Orzecznictwo Sądu Krajowego w Krakowie $(X I X / X X w$.$) .$

W ramach Sekcji III referaty przedstawili Piotr Krzysztof Marszałek z Dolnośląskiej Szkoły Wyższej Edukacji TWP we Wrocławiu - Realizacja swobód wyznaniowych w strukturach sit zbrojnych II RP, dr Zdzisław Zarzycki z UJ - Nienawiść religijna i rasowa jako 
przyczyna sporów matżeńskich w świetle orzecznictwa Sąu Okręowego w Krakowie w okresie II wojny światowej, dr Pawel Borecki z UW - Laickość państwa w świetle dorobku wspótczesnego konstytucjonalizmu (po 1945 r), dr Paweł Leszczyński z Państwowej Wyższej Szkoły Zawodowej w Gorzowie - Czeskie państwo wyznaniowe - dziedzictwo przesztości i profil wspótczesny, dr Marcin Zaborski z KUL - Ustrój adwokatury w Polsce w latach 1944-1963. Zarys problematyki, dr Piotr Fiedorczyk z UwB - Unifikacja i kodyfikacja prawa rodzinnego na tle stosunków pomiędzy państwem a Kościołem katolickim w Polsce (1944-1964), dr Andrzej Pasek z UWr - Przejmowanie majątku kościelnego na Dolnym Ślq̨sku przez duchowieństwo polskie po zakończeniu II wojny światowej, dr Wojciech Sławiński z KUL - Rewindykacja majątku Kościołów ewangelickich na przykładzie byłej gminy ewangelickiej w Chetmży, dr Marcin Lysko z UwB Dziatalnośc duszpasterska Kościoła katolickiego w swietle prawodawstwa i praktyki władz okresu gomutkowskiego, mgr Marek Stus z UJ - Stosunki między państwem a islamem we Francji w świetle ustawodawstwa oraz praktyki prawno-politycznej (1905-2005).

Popołudniowe Obrady plenarne w Collegium Jana Pawła II otworzył prof. Wacław Uruszczak. Ks. dr hab. Franciszek Longchamps de Bérier z UW omówił problem Neutralnego państwa religijnych obywateli w jurysprudencji Sadu najwyżzzego, prof. dr hab. Tomasza Kruszewskiego z UWr - VI Sejm Prowincjonalny na Ślasku $w 1841 r$ wobec problemu handlu w niedziele, prof. dr hab. Józef Ciągwa z URz - Kościót krakowski a jezzykowe prawa mniejszości stowackiej na Spiszu i Orawie w latach 1920-2005.

Po przedstawieniu referatów odbyła się dyskusja, a następnie Przewodniczący poszczególnych Sekcji, piątkowych i sobotnich dokonali podsumowania obrad Zjazdu. Głos zabrało również wielu uczestników. Temat, który najczęściej powracał, dotyczył sposobu prowadzenia badań archiwalnych oraz przyszłości nauk historyczno-prawnych.

Ogólnego natomiast podsumowania Zjazdu Katedr Historyków Państwa i Prawa dokonal prof. Jerzy Walachowicz z UAM. Przede wszystkim odniósł się do tematu tegorocznego Zjazdu. Podzielił się 
z zebranymi spostrzeżeniem o wciąż żywej obecności zasady Cuius regio eius religio, choć od jej powstania minęło już kilkaset lat. Wyraził wdzięczność za tak liczne przybycie oraz za przedstawienie tak wielu interesujących referatów. Podkreślił, iż szczególnej radości przysparza mu fakt, iż ponad połowa $z$ nich należała do młodszych pracowników naukowych. Profesor nie szczędził jednak także słów krytyki w stosunku do referatów, które uznał za zbyt długie, i zaapelował, aby w przyszłości skrócić czas przewidziany dla prelegentów, zaś wydłużyć czas na dyskusję.

Zamykając Zjazd Historyków Państwa i Prawa w 2006 r. prof. Grzegorz Górski gorąco podziękował przybyłym za obecność, wytrwałość i wyrozumiałość. Szczególne zaś dziękował dr Marzenie Lipskiej i dr Leszkowi Ćwikło z Katedry Historii Państwa i Prawa KUL za przygotowanie Zjazdu.

Elżbieta Loska*

* Uniwersytet Kardynała Stefana Wyszyńskiego. 